\title{
GENDER, MIGRATION, AND MAGICAL NATURALISM IN EDGAR REITZ'S DIE ANDERE HEIMAT (2013)
}

\author{
Rachel Palfreyman \\ (UNIVERSITY OF NOTTINGHAM)
}

\begin{abstract}
A gendered understanding of the concept of Heimat exposes difficulties with gender representation in Heimat film and writing in both the traditional and critical modes. Women can be so closely aligned with the construction or even embodiment of the Heimat that their own access to it is in doubt. Reitz's Heimat (1984) was criticised as well as celebrated for its representation of the maternal Heimat constructed by Maria seemingly for the benefit of her menfolk who are able to transcend the Heimat and then return, while she remains stuck in the Heimat realm. Reitz's Vormärz prequel Die andere Heimat (2013) on the face of it presents another narrative of a mother and her sons with a fraternal and mirrored gender pattern of Heimat production, as well as dealing with the complexities of leaving and remaining in the Heimat. In engaging both with current debates on the intersection of Heimat discourse and migration, and with the birth of the Heimat movement, this essay 'bookends' the core period addressed in this special number, as it looks forwards and backwards to historical and conceptual concerns that anchor the discussions of Heimat texts from 1871-1933.
\end{abstract}

Eine auf Gender bezogene Auseinandersetzung mit dem Begriff Heimat deckt Schwierigkeiten der Genderdarstellung sowohl in traditionellen wie auch in kritischen Repräsentationen auf, sei es im Heimatfilm oder in der Literatur. Frauenfiguren werden häufig so eng mit der Heimat identifiziert, dass sie, indem sie selbst die Heimat verkörpern, den eigenen Zugang zur Heimat riskieren. Reitz' Film Heimat (1984) wurde für seine markante Darstellung der mütterlichen Heimat gelobt wie auch kritisiert: Die Hauptfigur Maria baut anscheinend zum Vorteil ihrer Männer und Söhne eine heimelige Innenwelt, aus der die Männer austreten können, um dann heimzukehren, wann immer sie es wollen, während Maria im Reich ihrer Heimat stecken bleibt. Oberflächlich betrachtet präsentiert das Vormärz-Prequel Die andere Heimat (2013) eine weitere MutterSöhne-Geschichte, die zudem noch einen brüderlichen Konflikt in den Vordergrund stellt. In diesem Aufsatz wird aber gezeigt, dass die Heimatkonstruktion im letzteren Film komplexe und spiegelverkehrte Geschlechterstrukturen sichtbar macht und sich auch mit den Schwierigkeiten des Fortgehens und Dableibens auseinandersetzt. Indem sich dieser Beitrag also sowohl heutigen Debatten über Schnittpunkte des Heimatdiskurses, der Migration und der Geburt der Heimatbewegung im 19. Jahrhundert widmet, klammert er den Kernzeitraum dieser GLL-Sondernummer dadurch ein, dass er die relevanten historischen und begrifflichen Anliegen vorausschauend und rückblickend reflektiert, die als Fixpunkte für Diskussionen zum Heimatbegriff 1871-1933 dienen.

Edgar Reitz's television series and feature films have had a crucial influence on artistic,

popular and critical engagement with the genre of the Heimat film. While his work

(especially Heimat) has divided critics, ${ }^{1}$ audiences both international and domestic have responded supportively. ${ }^{2}$ Alexandra Ludewig comments that Reitz's work has been 'responsible for a renaissance of the concept in all strata of German society', and his influence is discernible in the wider deployment of Heimat as a critical category. ${ }^{3}$ Following the Heimat trilogy and its epilogue, Reitz's 2013 production Die andere Heimat returns to Schabbach, but, with the action set in the 1840s 'Vormärz', it presents a distant prequel to the 
twentieth-century Schabbach of the earlier films. By going back in time to the 1840s, Reitz presents a lead-up to the great flowering of Heimat art and discourse of the late nineteenth and early twentieth century as he explores a world just starting to experience the dramatic demographic shift to industrial towns and cities which gathered such momentum in the later nineteenth century. ${ }^{4}$

At the same time as an incipient industrialisation begins to be a factor in drawing people away from rural communities, however, a different and more pressing sense of Heimat as something irrevocably lost is conjured by the great wave of migration from the Hunsrück to Brazil and other places in the so-called New World. The mass migration of the 'Vormärz' invites us to contemplate a proto-Heimat discourse emerging at a point when mass schooling contributes to the development of a literate folk culture, which is in turn shown interacting with the post-Enlightenment developing academic discipline of anthropology. ${ }^{5}$ For this is where, for Reitz, Heimat begins in his Heimat prequel - with loss, to be sure, experienced in the trauma of migration, the historical dislocations and ruptures, the raw poverty which 'pushed' people away from their homes, but also with a crucial 'pull' to a Heimat doubled by such loss, a 'pull' to another Heimat which is inspired by reading. Longing ('Sehnsucht') thus encompasses the need for a viable home free of poverty and repression, but also a Heimat imagined in dreams of a better life and read about in travel literature and tales of adventure. ${ }^{6}$ Mass literacy in the Hunsrück, combined with the political and social circumstances of migration, stands in Die andere Heimat as the symbolic beginning of Heimat discourse. ${ }^{7}$

Reitz thus traces an arc back from current, twenty-first century preoccupations, where the concept of Heimat offers a framework for reading migration, and creates something akin to a prequel of the emerging Heimat genre, which is born not just of loss and separation, but depends, too, on the gain of public literacy. At the same time, the film explores gender in 
ways which not only complicate gendered notions of Heimat, but also connect to Reitz's first Heimat film, set in the period 1919 to 1982 , casting both gender structures and the dynamic of Heimat and its other in a different light. Reitz's engagement with a proto-Heimat discourse in Die andere Heimat sets the historical scene for his first film series, stakes a claim for a reading of the concept that operates before the Heimat movement proper came into being, and, with its attention to migration and its reading of gender in Heimat, is patently also of the now.

In its exploration of the Heimat genre and concept, the first film series has been criticised as participating in a 1950s patriarchal conception of Heimat: Maria is trapped, bearing the burden of embodying the Heimat for menfolk who are able to transcend it in various ways, emigrating, as Paul does, and achieving success as an electronics pioneer in the US, or through art, as in the case of Hermann, for whom the Heimat figures as a complex and fractured source of inspiration. ${ }^{8}$ Arguably, Heimat is a narrative of mothers and sons, but not one which offers much to challenge well established gender patterns. ${ }^{9}$ In all the subsequent films, from Die zweite Heimat with its stronger focus on Clarissa and other women artists seeking transcendence and accommodation with complex notions of belonging, to the Heimat Fragmente (Die Frauen) with its out-takes providing supplementary information about women characters, the gender dynamic is addressed differently, offering an apparent corrective or rebalancing.

On the face of it, the prequel Die andere Heimat is another, potentially disappointing confirmation that Heimat is something conjured by women for the benefit of men, a shadowy nether world where women function to maintain an interior domestic sanctuary while men are able to leave and return. It is, after all, a story of two brothers - Jakob, the one who dreams of leaving, but has to stay, and Gustav, the practical, more adventurous one, who has no such 
dreams, but who in the end does leave, taking with him his wife Jettchen - the woman Jakob had first fallen in love with.

The film was partly inspired by Reitz's brother Guido who (as Reitz only discovered after Guido's death) was a lifelong student, from his Hunsrück home, of the comparative linguistics of indigenous languages of the Americas. ${ }^{10}$ In another fraternal motif, Reitz's 'brother' film-maker Werner Herzog appears in the role of Alexander von Humboldt alongside Reitz's own cameo as a local directing him towards Schabbach - thereby doubling and intensifying the contrast between the 'stay-at-home' brother and the 'want-away' brother, with Herzog famous, indeed notorious, for his film-making exploits in South America, while Reitz's films have been made in Germany or Austria, and what he is most known for is a return to his home region to make the epic film cycle Heimat.

The casting of Marita Breuer as Margarethe, the mother of Jakob, Gustav, and Lena, might be seen as a further iteration of a maternal Heimat that is neither resolved nor sufficiently problematised. Margarethe's relationship with her sons and her symbolic representation of the Heimat recalls the first film series, where Breuer, then in her late twenties, played the nineteen-year-old Maria Wiegand, right through to the eighty-two-yearold Maria Simon, the matriarchal heart of the Heimat. However, I want to argue that, starting with the gender structure and encompassing a number of different markers of alterity and opposition, Die andere Heimat offers a different way of reading the Heimat concept.

\section{THE WOMAN MIGRANT}

For all its fraternal motifs, apparent love triangle, male protagonist, and autobiographical origins in the story of Guido Reitz, Die andere Heimat does not position women in the same way as the first film does. The rivalry between the brothers might appear to show Jakob thwarted by his brother Gustav: Gustav not only marries Jettchen, whom Jakob loves, but 
also appropriates Jakob's dream of emigration to the New World, since Gustav's emigration means that Jakob must stay to look after the forge and care for his ageing parents. Yet it is not Gustav, but Jettchen who has made the decision that the couple will emigrate. Jettchen and Gustav are grieving for their baby daughter Mathildchen, who died of diphtheria at six months. Jettchen is also unsure how to manage the difficulty of living at close quarters with both Gustav and Jakob and takes decisive action. We do not witness the dialogue between Jettchen and Gustav, though we are aware it is taking place while they are locked in their bedroom, with the rest of the family desperately concerned about their wellbeing. Their decision is presented prominently when Gustav speaks to the whole community in church of their resolve to join those leaving for Brazil.

It is clear, however, and has been explicitly stated by Reitz in the book of Die andere Heimat published to accompany the film, that the decision to leave is Jettchen's. ${ }^{11}$ Her voice is not heard as such, but she is presented as the real impetus for their emigration, standing beside him in church with the focus much on her face as he quasi-recites the words that are actually hers, and later sitting alone atop the covered wagon - 'enthroned', as the script has it - while Gustav leads the horses to join the great trek from the villages. ${ }^{12}$

It is the woman, here, who has resolved to leave the Heimat for the New World, contrasting with the departure of Paul to the United States in the late 1920s in the first Heimat series: he, as it were, steals away, and then returns in rather estranged fashion at intervals up to the early 1980s, and even retains his right to inherit the forge and house in Schabbach. In Die andere Heimat, the fraternal conflict is a sleight of hand, a trick done with mirrors, or a kind of front for the covert core of the film, which is not about Jakob remaining and Gustav leaving, but about Jakob stuck, and Jettchen flying free - with their respective partners, Gustav and Florinchen, Jettchen's best friend. Indeed, in a further inversion of gender clichés, 
it is Jakob who is trapped by family responsibilities, as the last remaining child of Margarethe and Johann.

What is fundamentally different from Paul's later emigration in Heimat, however, is the permanent nature of this move. The distress of the families in the run-up to the migration and the general mood of solemnity (at best) in the village, both among those preparing to emigrate and those preparing to lose their loved ones, reflects the desperate gamble that is being taken. The passage to the Americas is dangerous, the situation in Brazil uncertain, and for people of their means and social class, it is implied, there is no going back. ${ }^{13}$ The emigration is fraught with the weight of this 'forever', and is profoundly different from Paul just slipping out, eventually to come back expecting to pick up where he left off, in his marriage at least.

Jettchen's leave-taking is positioned as a magic crossing-over, a splitting-off from her old life to become something entirely new. Her departure is not at all quiet or unheralded. It is announced in church, with Gustav and Jettchen interrupting the service to announce their plan to the whole community, and there are extensive preparations, from dealing with the wagons and hire of the horses, to the emotional fallout of Gustav usurping Jakob's dream, as well as the grief of their parents. Jettchen is leaving behind the grave of her baby daughter as well as her first love Jakob; as part of her extensive preparations for the passage, she has sex with Jakob, as if for old time's sake, or to settle the unfinished business between them.

Jettchen's farewell to her old life in Schabbach is depicted in one of the most selfconsciously striking scenes of the film. As she takes one last look in the mirror she is doubled and split off from her mirror-sister. She waves goodbye to her old self and leaves her behind in the mirror, so that there is a ghost of Jettchen left in the Heimat as she crosses over. The 'ghosting', the emphasis on passage and transition, the sense of loss and bereavement all point to a more drastic departure than Paul slinking away in the late 1920s. Indeed, the 
procession to join the great trek follows the same route, initially, as that taken for the funeral of the tiny diphtheria victims, and Jettchen has to tear herself free of her recently widowed mother ('das ist ja genug, Mutter' are probably the last words Frau Niem will ever hear her daughter say), investing the departure with the force of permanent separation. Yet the painful splitting of the self and desperate decision to emigrate is not a death, but rather a magical transformation which proceeds in ritual fashion: the burial of the agate crystal in the daughter's grave, sex with Jakob in the graveyard, the invocation of the mirror-self, the apparition in the mirror, and then the final separation and doubling.

In Jettchen's first encounter with Jakob we see the start of a process of her becoming other and transitioning quasi-magically to the other realm that Jakob so idealises. She and Florinchen are both naked out in the fields experimenting with a folk cure when he sees them. Here, Jakob's imaginative world sees him performing, as it were, fieldwork in his research project, peering out at the mysterious and frightening native women, who are, of course, naked and performing an incomprehensible and hitherto unrecorded rite. Jakob, as Heimat ethnographer, tells a hastily dressed Jettchen about his academic study of the New World, focused through a study of the comparative linguistics of indigenous peoples. He tells her about South American birds as big as she is, such as the condor or the pelican, and she leaps about trying to fly, making the sounds she imagines a human-sized bird might make, performing the unknown creature in flight and in its uncanny cries.

In all their communication about the New World, Jakob is the theoretician and Jettchen the practitioner. She is the one who tries out the language he teaches her by greeting him in the language he studies (a practitioner of communicative, rather than grammartranslation methods). She is the one who actually leaves for Brazil, and whose report back exposes the stark contrast between a theory of adventurous encounter with alterity and the practice of colonialism: she reports that there are in her vicinity no native South Americans 
on whom she could practise her greeting; that snakes must be driven out, and the rain forest cleared for cattle farming; a house with a lockable door is a significant milestone.

As Jakob begins to read the letter, we are not sure whose words he is reading. The family rejoices because 'der Gustav hat geschrieben', but after a few lines, when Gustav is referred to in the third person, it becomes clear that this is Jettchen's letter. It is Jettchen who tells their tale of having made it across the ocean, and she is the one with the actual experience of the rainforest, the snakes, and the immense adventure of the other side. The native American language Jakob has researched functions as a code between them. Jettchen surmises that it will be Jakob who reads the letter to the family and alludes to the private connection between them by closing her text with the words he taught her for 'Can you keep a secret?'

The film's celebration of Jettchen's firm resolve to cross over, the woman migrant, the woman who has flown the Heimat, is not designed to denigrate Jakob's imaginative dream, or theory per se. In Reitz's mirrored depiction of the Heimat and its other, Jakob's book learning is the origin of Jettchen's liberation from the Heimat. On the one hand, knowledge through reading, language, and letters, and on the other, application, action, and practice are shown to form a mutually dependent opposition, a dynamic interplay which is another of Reitz's Heimat dialectics. The theoretical knowledge obtained by Jakob and the practical experience lived by Jettchen do not operate as a fixed and stable opposition. Indeed the interplay between them gestures to the emergence of Heimat discourse, where the relationship between individuals, land, and community is idealised as harmonious and sustainable. 


\section{LITERACY AND THE CONSTRUCTION OF HEIMAT}

The generation of Jakob, Gustav, Florinchen, and Jettchen is the first rural generation to have experienced universal compulsory elementary schooling in Prussia, and thus can read and write, albeit to different degrees, despite coming from relatively poor artisan families. ${ }^{14} \mathrm{We}$ see something of a generational divide between them and the older generations who cannot all read, though attitudes to the literacy of the younger generation vary: Johann sees the scholarly Jakob as work-shy, whereas Margarethe understands the value of reading since a letter is her only hope of news from Brazil.

Jakob's scholarship goes far beyond the basic literacy of others in his generation. Gustav struggles rather, especially with the official language he encounters in the preparations for emigration; Florinchen is a singer and closer to an oral tradition; and Jettchen is often silent, learns by listening to Jakob, and is inspired by visual representation and performance. Jakob's extensive reading and study represent his crossing-over, his own passage to another Heimat, one of his own creation through his anthropological and linguistic research. He regularly runs away from the labour of forge and field in order to avoid being punished for reading on the job, as he has no room at home in which to read. The natural environment becomes his study, and as he passes through the Hunsrück hills and woods he appears by the force of his linguistic invocation to transform them into an uncanny version of the South American rain forest. Thus, focalised through his creative desire, the Hunsrück Heimat reveals its other, or at least a version of its constructed, idealised other. In something between a magic spell, a stepping through the back of the wardrobe, or perhaps a feat of the imagination akin to a children's game of Native American scouts and hunters, the Heimat landscape is converted into the other Heimat: Jakob changes Jettchen into a condor or an albatross capable of traversing immense oceans, and conjures the falcon out of the book he is reading. 
Jakob's approach scarcely seems academic, but we learn that his scholarship is not just the work of a naive enthusiast, for it is respected by a luminary such as Alexander von Humboldt, who takes a detour on a journey from Paris to Berlin to consult this strange backwater scholar who is clearly an expert 'in the field', despite not having travelled to the New World. Jakob's combination of supernatural creativity, immersion, and radical openness to the object of his study sidesteps crude and racist anthropology to develop an anthropological linguistic discourse which blurs the boundaries between Heimat and its other.

Neither Jakob nor Jettchen exist in purely masculine or feminine modes of existence. In many ways Jakob is feminised, in that he is presented as weak, the fey dreamer who is not tough enough for forge and field, a literate creature who scampers through woods to perform his anthropological researches. Jettchen is more the true migrant than either Jakob or her husband Gustav; she is, as it were, Jakob's student, the only one in the Hunsrück and later outside it, with whom he communicates in the languages of South America. She, too, is a writer, an adventurer, and a visual dreamer guided and inspired not by written texts, but by Jakob's instruction and the seascape captured in an agate crystal given to her by her silent father.

It would be possible to read Florinchen and Jettchen as a version of a Heimat gender dualism common in the genre: the Heimat woman and the exotic woman. But this too would be reductive. First, Jettchen and Florinchen resist such categorisation, for Jettchen, the questing spirit, is also a mother, while Florinchen, Jakob's Heimat wife, is a performer, an artist, often the preserve of the eroticised other. Second, it would be just as easy to see such a division in the two men: Gustav, the masculine one, the physical one, the soldier who emigrates (except that it is his wife who determines this); and Jakob, the bookish one, the slight, gentle boy who plays at being an Indian and cannot go anywhere except in his dreams, because he is the last sibling, left to look after ageing parents. It is not that there is no contrast 
being drawn between those who fly and those who stay, but more that this is not pinned to an essentialised feminine dualism, but functions across feminised men and confident, resolute women.

\section{MIGRANTS AND COLONISTS}

In fracturing classic Heimat gender structures with a woman migrant, and introducing the self-reflexive elements of Jakob's anthropological research, Reitz evokes the birth of a Heimat discourse in the period when a first literate generation of ordinary folk experiences loss and dislocation. This film undertakes an inverted examination of Heimat and migration, Heimat and its other. Reitz likes to look at things from odd, seemingly perverse angles. His presenting twentieth-century German history from the perspective of a Hunsrück village, and considering (in Heimat 3) the 'Wende' from the perspective of the Günderrode house overlooking the Rhine, are cases in point. In Die andere Heimat he looks at migration transposed to the nineteenth century, out of Germany and westwards. Like Jakob, the viewers never actually make it to Brazil; the other Heimat remains an idea, a dream, the sense of longing embodied in the title.

A classic trope of Heimat films is deployed here, with contemporary anxieties from the time of the film's production displaced back in time and to another place. The urgent need to focus on migration from the perspective of those who make the difficult decision to leave is figured in Die andere Heimat as a migration westwards and away from Germany, presented to audiences at a time when migration towards Germany from the east or the south is actually at issue. A number of experiences described by Jettchen in her letter point to present concerns about migration: the danger of the passage, with children especially at risk of dying; being ripped off by ruthless traffickers; needing to pay extra for food on the ship despite having paid for it already; arriving to be housed in miserable collective 
accommodation; finding that papers and promises are worthless; depending on luck and occasional helpful people to make any kind of progress.

Historically, the Hunsrïcker were seen as valuable colonists almost precisely because they were so poor and wretched in their homeland. They were susceptible to the tales of exotic adventure, riches, and advancement by professional recruiters. Their poverty also meant that they had typically learnt more than one trade as it was not possible to sustain a family on a smallholding diminished by the inheritance rules pertaining in the Hunsrïck; thus they were often smiths, tanners, or bakers as well as farmers, skills considered useful in the colonies. ${ }^{15}$ As colonists they occupy a problematic position in the film's historical and contemporary double vision. The colonist-migrants are both victims and perpetrators; they stand in certain respects for today's migrants fleeing persecution, poverty, and war. We are clearly being invited to empathise with the plight of those who throughout history - and today - must take this desperate gamble. Here Reitz connects the origins of the Heimat movement and genre in loss and dislocation with current concerns about migration in a globalised world. In early Heimat texts the implied dislocation is due to modernisation and urbanisation in particular. Today's bitter political disputes over the degree to which the developed world is willing to welcome refugees again point to discussions about the meaning of Heimat where rootedness has become an impossibility. Reitz brings these concerns sharply into focus by choosing a story that has migration across oceans at its heart. There is no sense that Reitz is denigrating 'Weggeher', as Gertrud Koch argued in relation to Heimat. ${ }^{16}$ But Reitz's migrants are colonists, too, so we are bound also to hear the uncomfortable silence of the indigenous voices of South America. Jettchen cannot greet native Brazilians who have been seemingly cleared away along with the forest, their language perhaps heard more in Schabbach in Jakob's study, or while out on his field trips into the Hunsrück rainforest. A scholarly anthropological and linguistic discourse on the languages of the Amazon marks 
their loss, constitutes and codifies them (in European terms) at their moment of destruction, just as Heimat writing emerges to create an imaginary wholeness between land and community at the very moment when such an imaginary bond recedes.

Margarethe's death occurs just before her son's letter from the New World arrives, and the last sequence in the film has Jakob burying Gustav's letter in the mound of earth over her grave. Interring the letter is positioned both as one of Jakob's magical, ritual acts and as a symbolic restoration of Gustav in written form to his bereft and deceased mother and to the Heimat earth. His gesture mirrors the parting gift of Heimat earth made to Gustav as he and Jettchen leave. Such a sign of attachment points to a desire to transport the untransportable, to re-purpose, detach, and relocate Heimat soil, and attempts to render non-essentialist the essentialist quality of Heimat. The practice has a history in migration and forced migration as well as colonialism. It was quite common for those fleeing westwards at the end of the Second World War, the 'Heimatvertriebenen', to take with them little bags of 'Heimaterde', souvenirs which had an iconic significance in Heimat associations, and which were sometimes offered as prizes in 'Heimatverein' raffles. ${ }^{17}$ The icon of Heimat earth or the overcoming of family separation by burying the letter from Brazil in the mother's freshly dug grave might make us think, too, of Rupert Brooke's 'corner of a foreign field / that is for ever England'; these symbolic manoeuvres both unsettle the essentialism of 'native' soil, by liberating it from its place of origin, and at the same time might be seen as problematically justifying colonialist appropriation, if 'Heimat' can function independently of birthplace through the investment of labour or a spiritual attachment.

In conclusion, Reitz's engagement with his brother's story has not just taken a different perspective on narratives of Heimat, but has thoroughly disrupted key tropes of the genre. Die andere Heimat does not just depict a fraternal rivalry about leaving and staying, but constructs a more even-handed gender discourse which moves beyond triangular love 
rivalries and dual hierarchies of the homely and the erotic, or indeed the masculine and the feminine, to an interdependent quartet where there is a fluid interplay between the four young people and an attitude to gender that challenges essentialism in terms of who leaves and who stays, as well as who creates, constructs, and embodies the Heimat. For this prequel to Heimat also dramatises a birth of Heimat creation that emerges between the four and unfolds after the emigration has taken place. The letter from Gustav that Jakob buries in Margarethe's grave, the Heimat earth, the mother's body, as well as the agate that Jettchen has buried in Mathildchen's grave just before leaving are all rather reminiscent of a magic ritual, a spell, a symbolic animation of the Heimat earth reborn as a cultural entity, something that is lost, dead, and gone, and yet brought into being in the sharp relief of its absence. Heimat culture Jettchen's cinematic agate held to the light, Jakob's ethnography, Florinchen's folk song, Gustav's craftsmanship - comes into being through the interplay, the bond, and the globally strung-out separation between the four young lovers. It is the other Heimat that magics the Heimat into being, and although this could be read as part of a realist historical narrative about the emergence of a literate folk culture on which the creation of Heimat discourse depends, it is also staged as part of a magical ritual orchestrated by Jakob that requires all four adepts to perform acts of crossing-over. The origins of Heimat and the stories of today's migrants illuminate each other as if by magic invocation. In the positioning of the four young protagonists, Die andere Heimat departs quite radically from gender essentialism, if not from gendered structures. And while there are undeniable risks in representing German colonists as victimised adventurers, the film succeeds in presenting a flickering interdependence between the Hunsrück as Heimat and the other Heimat, thus resisting and disrupting the familiar hierarchy of Heimat and its other. 


\section{FOOTNOTES}

1. For summaries of the divided early reception of Heimat, see Miriam Hansen, 'Dossier on Heimat', New German Critique, Special Issue on 'Heimat', 36 (Autumn 1985), 3-24; and Rachel Palfreyman, Edgar Reitz's 'Heimat': Histories, Traditions, Fictions, Oxford 2000, pp. 89-110.

2. According to ARD press releases, around 25 million viewers or $54 \%$ of the viewing public saw one or more episodes of Heimat in 1984 ('Kein Stammpublikum', Tagesspiegel, 20 November 1984). Between 2 and 3.3 million viewers watched in Britain in 1986, then a large number for a subtitled film on BBC2 ('Das Ereignis des Frühlings: "Heimat" in Großbritannien', Erstes Deutsches Fernsehen, ARD press release 24/1986).

3. Alexandra Ludewig, Screening Nostalgia: 100 Years of German Heimat Film, Bielefeld 2011, p. 31. For examples of the wider deployment of the 'Heimat' concept, see Daniel Grimley, Grieg: Music, Landscape and Norwegian Identity, Woodbridge 2006; Erica Carter, James Donald, and Judith Squires (eds), Space and Place: Theories of Identity and Location, London 1993; Maiken Umbach and Bernd Hüppauf (eds), Vernacular Modernism: Heimat, Globalization and the Built Environment, Stanford 2005.

4. Celia Applegate, A Nation of Provincials: The German Idea of Heimat, Berkeley 1990, p. 13. On the flourishing Heimat discourse and genre around the late nineteenth and early twentieth century, see Elizabeth Boa and Rachel Palfreyman, Heimat - A German Dream: Regional Loyalties and National Identity in German Culture 1890-1990, Oxford 2000, pp. 30-57.

5. For example, the pioneering anthropologist Lewis Henry Morgan conducted fieldwork with the Iroquois in the 1840s, and Adolf Bastian, the 'father of German anthropology', embarked on his first great research expedition in 1851. See Thomas Hylland Eriksen and Finn Sivert Nielsen, A History of Anthropology, 2nd edn, London 2013, pp. 20- 
43 (pp. 23 and 27). On the development of 'Volkskunde' in the early to mid-nineteenth century as an object of academic study, see Applegate (note 4), pp. 34-8. On Jacob and Wilhelm Grimm and the blurred boundary between literary and oral folk culture, see Fabian Lampert, 'The Turn to History and the Volk: Brentano, Arnim and the Grimm Brothers', in The Literature of German Romanticism, ed. Dennis Mahoney, Rochester, NY 2004, pp. 17189.

6. 'Regisseur Edgar Reitz: "Wer lesen konnte, wollte weg", Tagesspiegel, 30 September 2013, http://www.tagesspiegel.de/kultur/die-andere-heimat-regisseur-edgar-reitzwer-lesen-konnte-wollte-weg/8868846.html (last accessed 9 October 2017). See also Richard Gawthrop, 'Literacy Drives in Preindustrial Germany', in National Literacy Campaigns: Historical and Comparative Perspectives, ed. Robert Arnove and Harvey Graff, New York 1987, pp. 29-48 (p. 46).

7. After the Hunsrück became part of Prussia's Rhine Province in 1815 it was subject to Prussian 'Schulpflicht' for boys and girls, with a more concerted effort made to implement compulsory schooling even in rural areas where provision had been very patchy; see Peter von Polenz, Deutsche Sprachgeschichte vom Spätmittelalter bis zur Gegenwart, 3 vols, Berlin 1994-9, III, pp. 51-4. By the 1830s, when the protagonist Jakob Simon would have been in school, attendance of eligible children in Prussia was near 100\%; see Gawthrop, 'Literacy Drives in Preindustrial Germany' (note 6), p. 45. By around 1840 literacy in the territories which would become the 'Kaiserreich' had reached 82\%; see Reinhard Rürup, Deutschland im 19. Jahrhundert: 1815-1871, Göttingen 1984, p. 200.

8. Palfreyman, Edgar Reitz's 'Heimat' (note 1), pp. 177-92.

9. See Ruth Perlmutter, 'German Revisionism: Edgar Reitz's Heimat', Wide Angle, 9/3 (1987), 21-37 (24-5); Friedrich P. Kahlenberg, Gertrud Koch, Klaus Kreimeier, and Heide 
Schlüpmann, “"Deswegen waren unsere Muttis so sympathische Hühner” (Edgar Reitz).

Diskussion zu Heimat', Frauen und Film, 38 (1985), 96-106 (102-5).

10. Edgar Reitz, Die andere Heimat: Chronik einer Sehnsucht. Das Filmbuch, Marburg 2013, p. 203; see also ‘Guido Reitz beherrschte 50 Sprachen', Rhein-Zeitung,

https://www.rhein-zeitung.de/region/lokales/nahe_artikel,-guido-reitz-beherrschte-50sprachen-_arid,1049633.html (last accessed 20 March 2017).

11. Reitz, Die andere Heimat (note 10), p. 218.

12. Ibid., p. 173.

13. The nature of the promised parcel of land in the recruitment process meant that emigration to Brazil was understood as a permanent relocation, often of entire families, though some did in fact return, disappointed by the conditions they encountered. See Giralda Seyferth, 'Eine Erfolgsgeschichte - Die deutsche Einwanderung nach Santa Catarina', Brasilalemanha, http://www.brasilalemanha.com.br/novo_site/noticia/eine-erfolgsgeschichtedie-deutsche-einwanderung-nach-santa-catarina-von-prof-giralda-seyferth/7940 (last accessed 20 October 2017).

14. Reitz, Die andere Heimat (note 10), p. 200.

15. Ibid., pp. 200-2.

16. Gertrud Koch, 'Kann man naiv werden? Zum neuen Heimatgefühl', Frauen und Film, 38 (1985), 107-9 (108).

17. Jenny Graaf, 'After the expulsions: the lost German Heimat in memory, monuments and museums', PhD thesis, University of Nottingham 2014, pp. 59-60 and 194, http://eprints.nottingham.ac.uk/14478/1/finalcorrectedthesis11dec.pdf; Albrecht Lehmann, Im Fremden ungewollt zuhaus: Flüchtlinge und Vertriebene in Westdeutschland 1945-1990, Munich 1991, pp. 102-5. 